\title{
PENGARUH BENEFITS OFFERED APLIKASI MOBILE BANKING TERHADAP KEPUASAN NASABAH, KEPERCAYAAN, LOYALITAS DAN POSITIVE WORD OF MOUTH (WOM)
}

\author{
Oleh: \\ Ika Maret Tiana ${ }^{1}$ \\ RR Yulianti Prihatiningrum ${ }^{2}$ \\ Ahmad Rifani ${ }^{3}$ \\ Program Studi Magister Manajemen \\ Fakultas Ekonomi dan Bisnis \\ Universitas Lambung Mangkurat \\ E-mail: \\ Ikamarettiana81@gmail.com
}

\begin{abstract}
ABSTRAK
Penelitian ini bertujuan untuk menganalisa benefits offered aplikasi mobile banking (X) sebagai variabel eksogen terhadap kepuasan nasabah ( $\left.\mathrm{Y}_{1}\right)$, kepercayaan $\left(\mathrm{Y}_{2}\right)$, loyalitas $\left(\mathrm{Y}_{3}\right)$ dan positive WOM $\left(\mathrm{Y}_{4}\right)$ sebagai variabel endogen, studi pada nasabah bank di Indonesia. Metode penelitian ini menggunakan kuesioner dengan 153 responden nasabah bank yang menggunakan aplikasi mobile banking sebagai sampel dan telah dipilih dari populasi keseluruhan bank di Indonesia yang memberikan layanan dengan aplikasi mobile banking. Metode analisis data pada penelitian ini menggunakan teknik Structural Equation Model (SEM) AMOS Ver.24. Hasil penelitian membuktikan bahwa 1) benefits offered aplikasi mobile banking pengaruh signifikan terhadap kepuasan nasabah, benefits offered dilihat dari kemudahan dan keamanan pada penggunaan aplikasi mobile banking; 2) kepuasan nasabah berpengaruh signifikan terhadap kepercayaan, nasabah yang merasakan puas terhadap aplikasi mobile banking akan percaya bahwa aplikasi mobile banking yang digunakan dengan benefits offered memberikan keamanan dan kemudahan; 3) kepuasan nasabah berpengaruh signifikan terhadap loyalitas, dengan adanya kepuasan terhadap benefits offered pada keamanan dan kemudahan maka nasabah akan mengunakan kembali aplikasi mobile banking ; dan 4) kepuasan nasabah berpengaruh signifikan terhadap positive WOM, nasabah yang puas dengan benefits offered pada keamanan dan kemudahan memberikan reaksi tanggapan yang positif terhadap nasabah pengguna aplikasi mobile banking.
\end{abstract}

Kata kunci: benefits offered, kepuasan nasabah, kepercayaan, loyalitas, positive word of mouth (WOM). mobile banking 


\section{A. PENDAHULUAN}

Perkembangan teknologi semakin pesat hingga saat ini, dimana masyarakat tidak asing akan kehadiran teknologi khususnya pada penggunaan gadget. Gadget yang paling sering digunakan sekarang adalah smartphone. Smartphone yang dalam Bahasa Indonesia disebut ponsel cerdas yaitu telepon genggam yang mempunyai kemampuan dengan penggunaan dan fungsi yang menyerupai komputer.

Smartphone memiliki banyak aplikasi didalamnya,pengguna smartphone dapat menggunakan aplikasi yang sesuai dengan keperluan, mulai dari yang bersifat edukasi, bisnis hingga hiburan. Aplikasi yang banyak tersebut diinstal dari google play store. Google play store adalah layanan konten digital yang dimiliki oleh Google dengan menyediakan aplikasi seperti: toko daring untuk produk seperti musik, buku, aplikasi, permainan atau pemutar media yang berbasiskan operasi sistem android. Dengan adanya layanan tersebut, maka pengguna internet bisa mengunduh aplikasi yang mereka inginkan. Aplikasi ini operasionalnya lebih mudah dibandingkan jika harus membuka website yang memerlukan waktu tunggu setiap membuka kontennya. Dalam perkembangannya Google play store memberikan layanan aplikasi yang terhubung dengan layanan perbankan yaitu aplikasi mobile banking.

Lee Heijin et al. (2015) menyatakan bahwa mobile banking merupakan layanan terbaru setelah internet banking, dengan perkembangan mobile teknologi, memberikan layanan perbankan via perangkat smartphone, operator smartphone dan bank, dimana sebelumnya tidak memiliki hubungan bisnis, kini telah menjadi mitra aliansi, dimana keduanya sama-sama memiliki benefits offered meminimalkan biaya transaksi, sehingga kehadiran mobile banking ini telah membawa perubahan yang mendasar pada jenis layanan perbankan.

Menurut Tiwari dan Buse (2007) mobile banking yaitu pengiriman perbankan dan keuangan mulai dari layanan transaksi pasar saham, manajemen rekening bank dan mengakses disesuaikan informasi melalui perangkat telekomunikasi. Mobile banking telah muncul sebagai saluran komunikasi nirkabel untuk menciptakan nilai pelanggan dalam transaksi perbankan.

Aplikasi mobile banking dengan fitur yang sederhana membuat dimengerti pengguna. Semua intruksi diberikan secara mudah dan rinci sehingga efektif dan efisien dari segi waktu dan biaya dimana biaya tersebut lebih rendah dari online banking. Salah satu faktor bahwa bank telah mengefisienkan biaya dengan kemajuan di bidang teknologi yaitu pada layanan mobile banking dengan biaya rendah, adapun biaya tersebut seperti biaya transportasi, karena tidak harus mendatangi bank secara langsung, selain itu mobile banking memberi pelayanan 24 jam sehingga nasabah dapat melakukan transaksi kapanpun dan dimanapun bahkan ketika kantor bank sudah tutup (Zahra et al.,2012)

Menurut penelitian yang dilakukan oleh Financial Brand dalam International Journal of Bank Marketing yang menyatakan bahwa pada tahun 2015 terkait dengan lingkungan digital, beberapa trend yang ditetapkan untuk pasar dalam penyebaran pengiriman digital dengan cepat dengan desain aplikasi pada smartphone, menyebabkan peningkatan penjualan di bidang digital dan 
sosial, sehingga banyak penerimaan secara massal di pasar terkait pembayaran menggunakan aplikasi mobile banking (Sampaio et al., 2017).

Bank-bank yang sudah memberikan pelayanan melalui aplikasi mobile banking yang berada di Indonesia diantaranya adalah PT Bank HSBC Indonesia, PT Bank CIMB Niaga Tbk, PT Bank Sinarmas Tbk, PT Bank Central Asia Tbk dan PT Bank Mandiri Tbk, PT Bank Danamon Indonesia Tbk, PT Bank DKI, PT Bank NegaraIndonesia (Persero) Tbk, PT Bank Rakyat Indonesia (Persero) Tbk, PT Bank Tabungan Negara (Persero) Tbk, PT Bank Syariah Mandiri, PT Bank BCA Syariah dan PT Bank BRI Syariah (www.kalsel.antaranews.com).

Sampaio et al.(2017) menuliskan keterkaitan antara penggunaan aplikasi mobile banking dan kepuasan pelanggan dengan perbedaan budaya antar 3 negara yaitu Amerika Serikat, India dan Brazil. Penggunaan teknologi terkadang menghasilkan keuntungan dan kerugian, berdasarkan penelitian Sampaio et al. (2017) tersebut, benefits offered penggunaan aplikasi perbankan untuk smartphone dalam konteks aplikasi mobile banking di tiga negara yang berbeda (Brasil, India dan Amerika Serikat) untuk melihat pengaruhnya terhadap kepuasan dan pengaruh kepuasan terhadap kepercayaan, loyalitas dan positive WOM sehingga menghasilkan bahwa benefits offered berpengaruh positif dan signifikan terhadap kepuasan. Kepuasan berpengaruh signifikan terhadap kepercayaan, loyalitas dan positive WOM.

Bharti M. (2016) menyatakan bahwa benefits offered pada keamanan dan kemudahaan penggunaan aplikasi mobile tidak berpengaruh secara signifikan terhadap kepuasan nasabah bank. Penelitian Juniwati juga menyatakan bahwa tidak ada pengaruh signifikan antara keamanan dan kemudahan dengan kepuasan (Juniwati, 2015). Hidayat (2009) yang menyatakan bahwa kepuasan tidak berpengaruh langsung terhadap kepercayaan tetapi hanya memiliki hubungan secara parsial pada loyalitas.

Dengan latar belakang adanya perbedaan hasil dari penelitian sebelumnya, peneliti tertarik untuk meneliti apakah perbedaan pada setiap penelitian sebelumnya akan menjadi hasil yang berbeda pada penelitian ini, oleh sebab itu penulis tertarik untuk meneliti perbedaan hasil yang yang muncul dari penelitian terdahulu dengan judul "Pengaruh Benefits Offered Aplikasi Mobile Banking Terhadap Kepuasan Nasabah, Kepercayaan, Loyalitas dan Positive Word of Mouth (WOM). (Studi Pada Nasabah Bank Di Indonesia)".

\section{B. KAJIAN PUSTAKA}

\section{Pengertian Benefits Offered}

Benefits offered adalah manfaat yang ditawarkan, dalam aplikasi ini meliputi antara lain keamanan dan kemudahan penggunaan (Koksal, 2016). Chang dan Chen (2009) menjelaskan bagian benefit offered yaitu keamanan dan kemudahan penggunaan. Keamanan dianggap salah satu keunggulan aplikasi mobile banking, atribut utama yang dinilai oleh pelanggan yang melakukan transaksi keuangan melalui internet dimana hal inimenunjukkan persepsi pribadi yang melibatkan kemampuan intuitif pelanggan untuk menilai risiko yang 
dirasakan (Mitra,2016). Kemudahan penggunaan adalah keuntungan yang ditawarkan yang terkait dengan aplikasi untuk mobile banking seperti kemudahan navigasi interaksi dengan bank (Casaló et al., 2008).

Benefits offered menurut Kim J.M. et al. (2013) diukur melalui indikator adalah hemat waktu, hemat waktu dapat dilihat dari durasi waktu saat menggunakan aplikasi mobile banking, dalam setiap bertransaksi.

\section{Kepuasan}

Menurut Tjiptono dan Chandra (2009: 43) kata kepuasan (satisfaction) berasal dari bahasa Latin "satis" (artinya cukup baik, memadai) dan "facio" (melakukan atau membuat), dari kedua kata tersebut maka kepuasan dapat didefinisikan sebagai upaya pemenuhan sesuatu yang memadai.

Kepuasan pelanggan menurut Kotler (2012: 150) adalah perasaan senang atau kecewa yang muncul setelah membandingkan kinerja (hasil) produk yang dipikirkan terhadap kinerja (atau hasil) yang diharapkan. Kepuasan menurut Richard Oliver (Barnes, 2003: 64) adalah tanggapan pelanggan atas terpenuhinya kebutuhannya. Hal itu berarti penilaian bahwa suatu bentuk keistimewaan dari suatu barang atau jasa ataupun barang/jasa itu sendiri, memberikan tingkat kenyamanan yang terkait dengan pemenuhan suatu kebutuhan, termasuk pemenuhan kebutuhan dibawah harapan atau pemenuhan kebutuhan melebihi harapan pelanggan.

Nasabah menjadi pusat semua aktivitas perbankan karena persaingan yang semakin ketat untuk pangsa pasar yang lebih besar. Berfokus pada kepuasan nasabah telah menjadi kunci untuk meningkatkan kualitas layanan sesuai dengan harapan pelanggan di sektor perbankan (Hanson, 2000).

Pencapaian kualitas layanan yang tinggi bisa didapatkan dengan merencanakan strategi yang menjadi kebutuhan bank dalam suatu lingkungan yang kompetitif. Praktik kualitas pelayanan prima telah terbukti bahwa kepuasan nasabah bank secara signifikan akan mengarah pada loyalitas nasabah bank (Casaló et al., 2008). Dengan demikian, kepuasan secara keseluruhan dengan penawaran perusahaan ditentukan oleh perbandingan antara harapan terhadap produk atau layanan perusahaan dan persepsi mereka terhadap produk atau kinerja layanan (Fornell et al., 1992).

\section{Kepercayaan}

Sumarwan (2011: 165)menyatakan bahwa kepercayaan konsumen adalah pengetahuan konsumen mengenai suatu objek, atributnya, dan manfaatnya. Berdasarkan konsep tersebut, maka pengetahuan nasabah sangat terkait dengan pembahasan sikap karena pengetahuan nasabah adalah kepercayaan nasabah.

Kepercayaansecara umum dapat diartikan sebagai rasa yang dimiliki seseorang untuk mempercayai pihak lain dikarenakan pihak tersebut dapat memberikan sesuatu sesuai dengan apa yang diharapkan dan mempunyai integritas yang tinggi jika dihubungkan dengan kualitas seperti konsisten, berkompeten, jujur, adil, bertanggung jawab, sangat menolong, dan baik hati /kebajikan, untuk mempertahankan hubungan jangka panjang dengan para 
nasabah atau pengguna aplikasi mobile banking, pihak bank memerlukan suatu konsep untuk meningkatkan kepuasan nasabah(Arwani M. et al., 2011).

Pihak bank memerlukan nasabah loyal yang percaya terhadap aplikasi mobile bankinguntuk mempertahankan eksistensinya dalam era online banking. Kejahatan elektronik seperti pembobolan akun, penipuan penjualan dengan transfer secara online dapat memberikan penilaian kepada nasabah bahwa faktor kepercayaan menjadi hal yang sangat penting dalam penggunaan aplikasi mobile banking dalam transaksi perbankan. Konsep kepercayaan yaitu nasabah bank percaya terhadap keandalan pihak bank yang dapat menjamin keamanan dan kerahasiaan akun nasabah bank(Choi Hun et al., 2012).

Kepercayaan mengandung dua aspek yang berbeda yaitu kredibilitas yang merujuk kepada keyakinan bahwa pihak lain mempunyai keahlian dalam menjalankan tugasnya dan kebaikan yang merujuk kepada kesungguhan pihak lain bahwa pihak tersebut mempunyai kesungguhan untuk melaksanakan yang sudah disepakati (Kim Y.H. et al., 2013). Definisi tersebut memberikan penjelasan bahwa kepercayaan adalah komponen fundamental dari strategi pemasaran dalam menciptakan hubungan sejati dengan konsumen. Perusahaan perbankan yang beroperasi di bidang pelayanan membangun hubungan kerjasama dengan nasabahnya sebagai salah satu strategi bersaing.

\section{Loyalitas}

Menurut Lovelock dan Jochen (2010:338) loyalitas pelanggan yaitu kesediaan pelanggan untuk terus berlangganan pada sebuah perusahaan dalam jangka panjang, dengan membeli dan menggunakan barang dan jasanya secara berulang-ulang dan lebih baik lagi secara eksklusif, dan dengan sukarela merekomendasikannya kepada pihak lain.

Tantangan terbesar pemasar adalah memberikan kebebasan kepada konsumen, pemasaran yang terampil mempengaruhi motivasi maupun perilaku bila produk dan jasa yang ditawarkan sesuai desain untuk memenuhi kebutuhan pelanggan sesuai permintaan yang sudah ada atau sedang menunggu aktivasi oleh tawaran pemasaran yang tepat (Aaker A.David, 2013: 204).

Loyalitas nasabah secara luas mengacu pada perilaku nasabah yang menunjukkan keinginan untuk menjalin hubungan yang lebih baik dengan perusahaan, dalam hal ini kesediaan nasabah untuk menggunakan aplikasi mobile banking, yang memiliki kemudahan pada pelayanan perbankan, atau merekomendasikan aplikasi mobile banking kepada orang lain atau nasabah lain dapat menjadi indikasi keinginan nasabah untuk mendapatkan kemudahan dalam bertransaksi dalam perbankan dimana hal tersebut menunjukkan seberapa banyak nasabah terkait dengan bank (Chang dan Chen, 2009).

Setiap organisasi di pasar bersaing mengembangkan metode lanjutan untuk tetap mengikuti perkembangan pada bidang teknologi, misalnya mempengaruhi industri jasa melalui memberikan pelayananan online yang senantiasa memenuhi kepuasan pelanggan merupakan satu cara untuk mencapai loyalitas pelanggan (López-Nicholas et al., 2008).

Nasabah yang puas dengan adanya suatu teknologi kemudahan dalam perbankan seperti aplikasi mobile banking mungkin akan kembali untuk 
menggunakan aplikasi mobile banking dimasa depan dan akhirnya menjadi setia, hal ini merupakan salah satu konsep formal yang didasari pemikiran di bidang pemasaran. Oleh karena itu hubungan antara kepuasan dan loyalitas telah terbukti pada sebagian penelitian dengan hasil penelitian bahwa ada korelasi yang kuat antara kepuasan dan loyalitas. Pada sektor jasa dalam dunia perbankan menunjukkan bahwa kepuasan merupakan bagian prediktor utama loyalitas (López-Nicholas et al., 2008).

\section{Positive Word of Mouth (WOM)}

Menurut Kotler \& Keller (2012:512) word of mouth marketing adalah kegiatan pemasaran melalui perantara orang ke orang secara lisan, tulisan, maupun alat komunikasi elektronik yang berhubungan dengan pengalaman pembelian jasa atau pengalaman menggunakan produk atau jasa.

Word of Mouth (WOM) memiliki kekuatan besar yang berdampak pada perilaku pembelian konsumen. Kotler dan Amstrong (2012: 139) menyatakan bahwa rekomendasi dari teman yang sudah dipercaya, asosiasi, dan konsumen lain berpotensi untuk lebih dipercaya dibandingkan dari sumber komersil, seperti iklan dan salespeople. Sebagian besar, word of mouth terjadi secara alami, konsumen mulai dengan membicarakan sebuah merek yang mereka gunakan kepada orang lain.

Keiningham et al. (2007) menyatakan Positive WOM adalah rekomendasi positif lisan atau tulisan yang dilakukan pada konsumen yang menggunakan barang atau jasa. Saluran komunikasi bersifat non personal atau pribadi. Menurut Kotler dan Amstrong (2012: 141) majalah, radio dan televisi, layanan online, dan situs web berkomunikasi dengan tingkat non-pribadi.

Nasabah yang setia terkadang menjadi salah satu sarana dalam bidang pemasaran perbankan, karena kesediaan mereka untuk menggunakan aplikasi mobile banking dan menyebarkan positive WOM serta menjadi salah satu sumber yang dapat diandalkan oleh bank untuk meningkatkan pendapatan dimasa akan datang (Sampaio et al., 2017).

Bank memiliki tujuan dalam setiap kinerja yang akan dilakukan dengan menunjukkan pentingnya positive WOM pada layanan keuangan, terutama dengan berfokus pada mobile banking. Pentingnya kepercayaan dan keamanan dalam mengembangkan positive WOM,merupakan hasil kepuasan setelah mendapatkan suatu pelayanan (Sampaioet al., 2017).

Positive Word of Mouth (WOM) didefinisikan sebagai kemauan pelanggan untuk merekomendasikan atau mendukung produk atau layanan setelah pengalaman berbelanja mereka (Maxham dan Netemeyer, 2012).

Studi pemasaran telah diterapkan dalam konteks e-banking bahwa pelanggan yang puas dengan penggunaan aplikasi mobile banking cenderung untuk berkomunikasi dengan teman dan pelanggan lainnya alasan untuk kepuasan ini, yang mengarah pada kecenderungan yang lebih besar terhadap positive WOM(Casaló et al., 2008). 


\section{METODE PENELITIAN}

Penelitian ini adalah penelitian kuantitatif, dimana penelitian ini dilakukan untuk mengetahui bagaimana pengaruh antar variabel dalam penelitian sekarang dan penelitian terdahulu, sehingga dapat diketahui hasil penelitian sekarang dengan ada kesamaan atau perbedaan.

Unit analisis adalah satuan tertentu yang diperhitungkan sebagai subjek penelitian /unit observasi atau hal yang diteliti (Ferdinand, 2014: 165). Unit analisis dalam penelitian ini adalah nasabah bank yang menjawab kuesioner. Nasabah bank tersebut menjawab kuesioner dengan pernyataan seputar layanan aplikasi mobile banking.

Pengukuran variabel penelitian dengan kuesioner diukur dengan tingkatan menggunakan skala interval 1(satu) sampai 10 (sepuluh). Skala interval yaitu alat pengukur data yang memiliki makna, walaupun nilai absolutnya kurang bernakna. Skala ini menghasilkan ukuran yang memungkinkan perhitungan rata-rata, standar deviasi, korelasi dan sebagainya. Pada penelitian ini menggunakan teknik skala bipolar adjektive yang merupakan penyempurnaan dari sematic scale dengan harapan agar respon yang dihasilkan merupakan intervally scale data dengan memberikan kategori ekstrim seperti "sangat tidak setuju" dan "sangat setuju" (Ferdinand,2014:206).

Penelitian ini menggunakan metode analisis dengan SEM (Structural Equation Modeling) dengan menggunakan AMOS, dengan model first order confirmatory factor analysis atau disebut Confirmatory Factor Analysis (CFA) yang didesain untuk menguji multidimensionalitas dari suatu konstruk teoritis. Variabel laten yang kita gunakan dalam penelitian ini dibentuk berdasarkan konsep teoritis dengan beberapa indikator atau manifest. Konfirmatori ini digunakan untuk menguji valid atau tidak indikator yang digunakan sebagai pengukur konstruk laten (Ghozali, 2017: 127).

\section{HASIL DAN PEMBAHASAN}

Hasil jawaban penelitian didapatkan dari data kuesioner penelitian yang disebar secara online melalui Whatsup application, link google form, dan Facebook, Bank BNI terbanyak digunakan oleh responden yang mayoritas adalah karyawan swasta dan berada banyak berada di wilayah Indonesia pada bagian pulau jawa, karena pulau Jawa merupakan bagian wilayah Indonesia yang memiliki jumlah penduduk yang terbanyak dan tingkat pertumbuhan ekonomi cukup tinggi sehingga layanan perbankan secara online dengan aplikasi mobile banking sering digunakan untuk mempermudah transaksi perbankan dengan aman dan mudah.pengguna aplikasi terbanyak pada bank BNI sebesar 27,45\% dengan jumlah 42 nasabah bank dibandingkan dengan nasabah BRI sebesar 20,26\% dengan jumlah 31 orang, nasabah Mandiri sebesar 24,83\% dengan jumlah 38 orang, nasabah BCA sebesar 26,79\% dengan jumlah 41 orang, nasabah Bank Permata sebesar $0,65 \%$ dengan jumlah 1 orang. Sampel yang diambil sebanyak 153 orang responden.

Berdasarkan karakteristik jenis kelamin yaitu laki-laki sebesar 63,4\% dengan jumlah 97 orang dan perempuan sebesar $36.6 \%$ dengan jumlah 56 orang. 
Berdasarkan karakteristik usia yang tertinggi yaitu berada pada usia 36-40 tahun sebesar $24,2 \%$ dengan jumlah 37 orang sedangkan sisanya yaitu usia 18-25 tahun sebesar 17 persen dengan jumlah 26 orang, usia 26-30 tahun sebesar 20,9\% dengan jumlah 32 orang, usia 31-35 tahun sebesar 22,9\% dengan jumlah 35 orang dan usia diatas 40 tahun sebesar $15 \%$ dengan jumlah 23 orang. Berdasarkan karakteristik pekerjaan terbanyak adalah karyawan swasta sebesar $41,83 \%$ dengan jumlah 64 orang.

Berdasarkan analisis deskriptif pada setiap variabel benefits offered yang diteliti menyatakan responden beranggapan bahwa dalam penggunaan aplikasi mobile banking pada penghematan waktu lebih dipilih dalam transaksi perbankan. Penghematan waktu dalam bertransaksi dengan menggunakan aplikasi sangat diutamakan pada benefit offered pada penggunaan aplikasi mobile banking. Nasabah tidak memerlukan waktu yang lama ketika melakukan transaksi mobile banking, hal tersebut dipilih daripada nasabah pergi bertransaksi ke bank atau atm.

Analisis deskriptif pada variabel kepuasan nasabah menyatakan responden beranggapan bahwa kepuasan karena tampilan yang menarik dan kepuasan pada keamanan dalam penggunaan aplikasi pada smartphone adalah hal yang utama, jika nasabah merasakan kepuasan karena benefits offered pada tampilan aplikasi dan keamanannya, nasabah tidak khawatir dalam bertransaksi perbankan dengan aplikasi pada smartphone.

Analisis deskriptif pada variabel kepercayaan menyatakan responden beranggapan bahwa aplikasi yang mendukung transaksi perbankan pada smartphone adalah hal yang utama, jika nasabah merasakan percaya karena aplikasi dapat mendukung aktivitas nasabah dalam bertransaksi maka nasabah memilih aplikasi tersebut pada smartphone dan tidak memilih aplikasi lain yang tidak mendukung aktivitas transaksi perbankan, ini menunjukkan bahwa nasabah percaya aplikasi mobile banking memang memberikan layanan perbankan yang mendukung setiap transaksi nasabah.

Analisis deskriptif pada variabel loyalitas menyatakan responden beranggapan bahwa aplikasi mobile banking menjadi pilihan pertama karena aplikasi tersebut dapat membantu nasabah dalam bertransaksi dengan smartphone. Setiap nasabah menginginkan adanya kemudahan bertransaksi maka mereka memilih aplikasi yang membantu transaksi perbankan, sehingga mereka memilih aplikasi mobile banking pada smartphone.

Analisis deskriptif pada variabel positive WOM menyatakan responden beranggapan bahwa memberikan saran positif mengenai aplikasi mobile banking kepada orang lain lebih utama sehingga orang lain dapat memberikan penilaian positif terhadap aplikasi yang digunakan untuk transaksi perbankan, jika layanan mobile banking dapat memuaskan nasabah, dengan sendirinya nasabah akan menyarankan orang lain menggunakan aplikasi mobile banking yang memudahkan transaksi perbankan.

Hipotesis penelitian ini diuji dengan menggunakan analisis SEM AMOS adapun hipotesis pada penelitian ini adalah sebagai berikut: 
Tabel 1. Scalar Estimates Maximum Likelihood Estimates: Regression Weights

\begin{tabular}{|c|c|c|c|c|c|c|}
\hline & & Estimate & S.E. & C.R. & $\mathbf{P}$ & Label \\
\hline Kepuasan & $<---\quad \mathrm{BO}$ & 1,275 & ,202 & 6,326 & $* * *$ & par_20 \\
\hline Kepercayaan & $<---$ Kepuasan & ,905 & 081 & 11,157 & $* * *$ & par_21 \\
\hline Loyalitas & $<---\quad$ Kepuasan & ,739 & ,082 & 8,969 & $* * *$ & par_22 \\
\hline PositiveWOM & $<---\quad$ Kepuasan & ,825 & ,079 & 10,475 & $* * *$ & par_23 \\
\hline & & \multicolumn{5}{|c|}{$* * *=0.0000$} \\
\hline
\end{tabular}

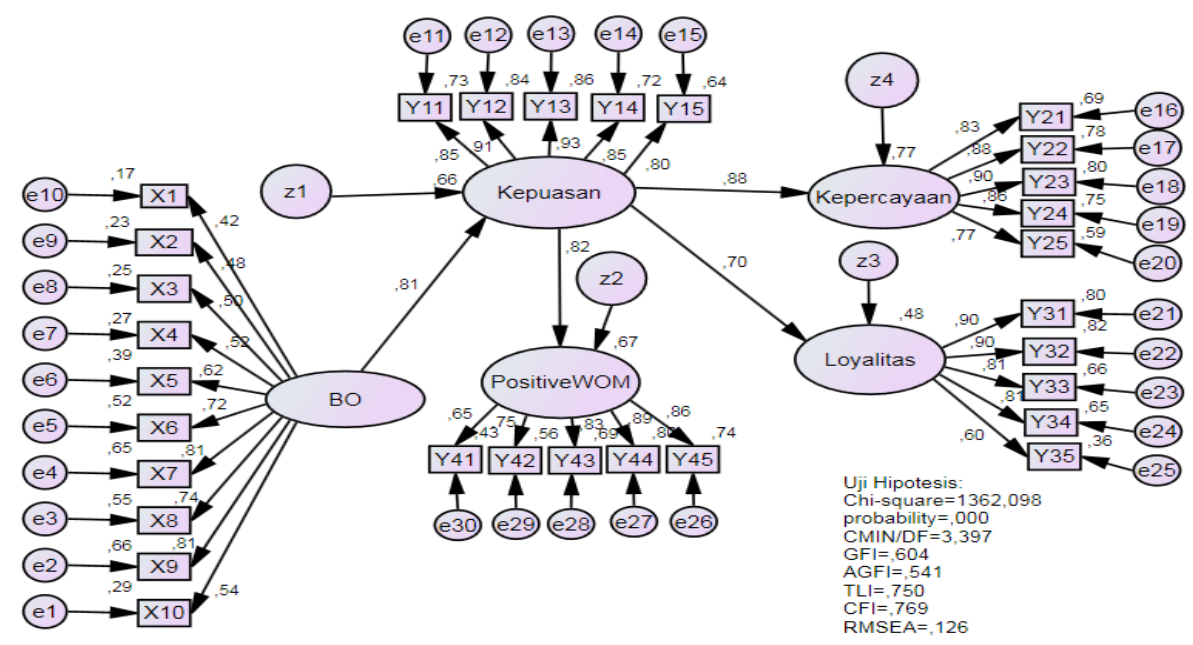

Diagram 1. Scalar Estimates Maximum Likelihood Estimates

\section{Benefits offered mempengaruhi kepuasan nasabah}

Aplikasi mobile banking memberikan keamanan dan kemudahan penggunaan pada transaksi perbankan hal ini dapat dilihat dari hasil pehitungan dari setiap indikator yaitu : keamanan transaksi dengan aplikasi mobile banking(X1.1), keamanan penggunaan dalam aplikasi mobile banking setiap saat (X1.2), rahasia informasi terjamin (X1.3), keamanan sistem aplikasi mobile banking (X1.4), kehandalan layanan aplikasi mobile banking (X1.5), kemudahan menggunakan aplikasi mobile banking (X1.6), kemudahan memahami menu aplikasi mobile banking (X1.7), kemudahan mengunduh aplikasi mobile banking (X1.8), sistem operasional (X1.9) dan hemat waktu (X1.10).

Sepuluh indikator yang mewakili variabel benefits offered menggambarkan bahwa aplikasi mobile banking memberikan kepuasan melalui keamanan dan kemudahan penggunaan. Hal ini menunjukkan aplikasi yang bermanfaat akan memberikan suatu kepuasan kepada penggunanya, dengan demikian manfaat produk yang didapatkan dalam penggunaannya akan mempengaruhi tingkat kepuasan nasabah bank pengguna aplikasi mobile banking.

Seluruh indikator benefits offered menunjukan nilai signifikansi terhadap kepuasan sangat baik, dengan demikian menunjukkan bahwa variabel benefits 
offeredmemiliki pengaruh yang signifikan terhadap kepuasan nasabah bank dengan nilai estimate yang baik, dan nilai critical ratio diatas standar yang telah ditentukan. Hal ini berarti bahwa benefits offered aplikasi mobile banking berpengaruh signifikan terhadap kepuasan nasabah bank, dengan demikian hipotesis 1 dapat diterima bahwa benefits offered aplikasi mobile banking berpengaruh signifikan terhadap kepuasan nasabah.

\section{Kepuasan nasabah bank mempengaruhi kepercayaan.}

Kepuasan dalam penelitian ini memiliki 5 indikator yaitu : kepuasaan penggunaan aplikasi mobile banking (Y1.1), kepuasan karena tampilan yang menarik(Y1.2), ketepatan pilihan (Y1.3), kepuasan dengan aplikasi mobile banking (Y1.4) dan kepuasan karena keamanan (Y1.5). Kelima indikator yang mewakili variabel kepercayaan yang diwakili oleh indikator-indikator sebagai berikut : kepercayaan transaksi aman dan mudah dengan aplikasi (Y2.1), informasi benar (Y2.2), aplikasi mendukung transaksi (Y2.3), kepercayaan pada layanan aplikasi (Y2.4) dan peran aplikasi mobile banking (Y2.5).Kelima indikator dari dua variabel tersebut terhubung satu sama lain.

Kepuasan aplikasi membuat nasabah akan bertindak, tindakan percaya terhadap aplikasi yang digunakan setelah memberikan kepuasan adalah hal yang dapat dijadikan penilaian tersendiri. Nasabah akan percaya jika aplikasi yang digunakan memberikan kepuasan pada diri nasabah tersebut, sehingga rasa puas yang ada mendorong nasabah untuk percaya bahwa aplikasi yang digunakan itu baik.

Kepercayaan nasabah terhadap aplikasi karena nasabah merasakan kepuasan saat menggunakan aplikasi mobile banking. Kepercayaan yang ada dihasilkan dari adanya kepuasan-kepuasan mengenai aplikasi sehingga kepercayaan muncul sebagai timbal balik dari rasa puas tersebut, dengan demikian hipotesis 2 dapat diterima bahwa kepuasan nasabah berpengaruh signifikan terhadap kepercayaan.

\section{Kepuasan nasabah bank mempengaruhi loyalitas.}

Loyalitas yang terdiri dari lima indikator yaitu: pilihan pertama (Y3.1), penggunaan kembali (Y3.2), keutamaan penggunaan aplikasi (Y3.3), penggunaan aplikasi terus menerus (Y3.4), dan keyakinan (Y3.5).

Kepuasan nasabah yang mempengaruhi pada loyalitas akan berdampak pada nasabah, yaitu nasabah akan memilih aplikasi mobile banking sebagai pilihan pertama, nasabah akan menggunakan aplikasi mobile banking kembali setelah sebelumnya adanya kepuasan nasabah bank setelah menggunakan aplikasi mobile banking, nasabah akan mengutamakan penggunaan aplikasi mobile banking karena aplikasi mobile banking yang digunakan memberikan kepuasan, hal tersebut akan mendorong nasabah menggunakan aplikasi secara terus menerus.

Nasabah yang puas setelah menggunakan aplikasi mobile banking akan memberikan tanggapan suatu tindakan yang dilakukan pada waktu mendatang, diantaranya seperti yang diwakilkan pada indikator- indikator variabel loyalitas. Kepuasan nasabah, akan memberikan keyakinan kepada nasabah bahwa aplikasi yang digunakan itu bermanfaat, dengan demikian bahwa hipotesis yang 
menyatakan kepuasan nasabah berpengaruh signifikan terhadap loyalitas dapat diterima. Hipotesis 3 yang menyatakan bahwa kepuasan nasabah bank berpengaruh signifikan terhadap loyalitas diterima.

\section{Kepuasan nasabah bank mempengaruhi positive WOM}

Positive WOM terdiri dari 5 indikator yaitu: rekomendasi kepada nasabah lain (Y4.1), rekomendasi kepada teman (Y4.2), rekomendasi kepada relasi (Y4.3), pemberi informasi positif (Y4.4) dan pemberi saran positif (Y4.5).

Kepuasan nasabah saat menggunakan aplikasi mobile banking berdampak pada positive WOM, dengan adanya rasa puas maka nasabah bank tersebut merekomendasikan aplikasi mobile banking yang digunakan kepada nasabah lain, merekomendasikan kepada teman, merekomendasikan kepada relasi. Nasabah yang merasa puas akan memberikan informasi yang positif mengenai aplikasi mobile banking, dan nasabah tersebut akan memberikan saran yang positif juga kepada orang lain agar menggunakan aplikasi mobile banking setiap transaksi perbankan.

Nasabah merasakan bahwa aplikasi mobile banking memiliki manfaat yang baik sehingga nasabahbank memberikan saran positif kepada orang lain. Hasil penelitian memperoleh nilai critical ratiodiatas standar yang ditentukan sehingga hipotesis 4 yang menyatakan bahwa kepuasan nasabah bank berpengaruh signifikan terhadap positive WOM diterima.

\section{E. SIMPULAN}

Menjawab masalah penelitian yang dikemukakan, kesimpulan penelitian ini adalah sebagai berikut:

Benefits offered aplikasi mobile banking berpengaruh signifikan terhadap kepuasan nasabah bank. Keamanan dan kemudahan penggunaan aplikasi mobile banking sangat mempengaruhi kepuasan nasabah.

Kepuasan nasabah bank berpengaruh signifikan terhadap kepercayaan. Kepuasan nasabah bank dalam menggunakan aplikasi mobile banking mulai dari keamanan dan kemudahan penggunaan sehingga nasabah percaya pada aplikasi mobile banking.

Kepuasan nasabah bank berpengaruh signifikan terhadap loyalitas. Kepuasan nasabah bank berdampak pada keinginan nasabah bank untuk terus menerus menggunakan aplikasi, dan menjadikan aplikasi pilihan pertama dalam bertransaksi perbankan.

Kepuasan nasabah bank berpengaruh signifikan terhadap positive WOM. Kepuasan yang didapatkan oleh nasabah bank menjadi salah satu penilaian positif terhadap layanan aplikasi mobile banking, sehingga nasabah bank akan merekomendasikan aplikasi mobile banking kepada nasabah lain, teman juga relasi. 


\section{DAFTAR PUSTAKA}

Aaker A. David (2013), "Manajemen Pemasaran Strategis" Edisi 8, Jakarta: Salemba Empat, Jakarta.

Arwani Mokhamad, et al. (2011), "Peran Karakteristik Individu Sebagai Moderator PengaruhKepuasan, Kepercayaan dan Komitmen Terhadap Loyalitas (Studi pada Nasabah Bank Syariah diKabupaten Kudus)", Jurnal Sosial dan Budaya, Vol. 4 Nomor 2, Desember, hlm. 159-170.

Barnes, James G. (2003), "Secrets of Customer Relationship Management: It's All About How You Make Them Feel”, New York: Mc Graw Hill

Bharti Mothwani (2016), “ Impact of Dimensions of Mobile Banking on User Satisfaction", Journal of Internet Banking and Commerce,Vol.21 No.1pp 122

Casaló, L.V., Flavián, C. and Guinalíu, M. (2008), "The role of satisfaction and website usability in developing customer loyalty and positive word-ofmouth in the e-banking services",International Journal of Bank Marketing, Vol. 26 No. 6, pp. 399-417.

Chang, H.H. and Chen, S.W. (2009), "Customer perception of interface quality, security, and loyalty in electronic commerce",Information \& Management, Vol. 46 No. 7, pp. $411-417$.

Choi Hun, Choi,Y.J., Kim Ki-Mun (2012), “The Understanding of Building Trust Model on Smartphone Application: Focusing on User's Motivation"Springer Science +Business Media B.V., pp 13-20.

Tjiptono, F., dan Gregorius Chandra (2009), “Pemasaran Strategik”, Penerbit Andi Pers, Yogyakarta.

Ferdinand Augusty Prof. (2014), Metode Penelitian Manajemen "Pedoman Penelitian untuk Penulisan Skripsi,Tesis dan Disertasi Ilmu Manajemen”, Edisi 5 Penerbit UNDIP Press, Semarang.

Fornell, C., Bookstein, F.L. (1992),“ Two structural equation models : LISREL and PLS applied to consumer exit-voice theory", Journal of Marketing Research(19:4), pp.440-452.

Ghozali Imam H.,Drs., Prof. (2017), "Model Persamaan Struktural Konsep dan Aplikasi dengan Program AMOS 24”, Penerbit Universitas Diponegoro, Semarang.

Hanson, W. (2000), Principles of Internet Marketing, Cincinnati, Ohio: SouthWestern.

Hidayat, Rachmad (2009)," Pengaruh Kualitas Layanan, Kualitas Produk dan Nilai Nasabah Terhadap Kepuasan dan Loyalitas Nasabah Bank Mandiri”, Jurnal Manajemen dan Kewirausahaan Vol.11 No.1 Hal.59-72 
Juniwati (2015), "Pengaruh Perceived Ease of Use, Enjoyment dan Trust Terhadap Repurchase Intention dengan Customer Satisfaction Sebagai Intervening pada Belanja Online" (Studi Pada Mahasiswa Universitas Tanjungpura Pontianak),Jurnal Ekonomi Bisnis dan Kewirausahaan Vol.4 No.1 hal.140-156.

Keiningham, T. L., Cooil, B., Aksoy, L., Andreassen, T. W., \& Weiner, J. (2007), "The value of different customer satisfaction and loyalty metrics in predicting customer retention, recommendation, and share-of-wallet", Managing Service Quality, 17(4), pp. 361-384.

Keller, K.L.(2012), "Strategic Brand Management: Building, Measuring and Managing Brand Equity", Prentice Hall.

Kim, J.M., Chung, N., Lee, M.W. (2013),"Motivation and Use Context in Mobile Tourism Shopping: Applying Contingency and Task-Technology Fit Theories", International Journal of Tourism Research 17, pp. 13-24.

Kim, Y.H., Kim, J., Watcher Kathy (2013), "A study of mobile user engagement (MoEN): Engagement motivations, perceived value, satisfaction, and continued engagement intention",Elsevier Journal Decision Support System 56 pp. 361-270.

Koksal, M.H.(2016), “The intentions of Lebanuese customers to adopt mobile banking",International Journal of Bank Marketing, Vol.34 No.3, pp.327-346.

Kotler, P. \& Armstrong, G. (2012),Principles of Marketing, New Jersey, Pearson Education.

Kotler, Phillip. Keller, Kevin (2012), Marketing Management 13/E, Prentice Hall.

Kotler, P. (2012), "Marketing Management: Analysis, Planning, Implementation, and Control", Prentice Hall, Upper Saddle River, NJ, USA.

Lee Heijin, Harindranath.G, Oh Sanjo, Kim Dong-jae (2015), "Provision of mobile banking service from an actor -network perpective: Implications for corvergence and standardization" Tecnology Forecasting \& Social Change Journal Vol.90, pp.551-561

López-Nicolas, C., Molina-Castillo, F.J. and Bouwman, H. (2008), “An assessment of advanced mobileservices acceptance: contributions from TAM and diffusion theory models", Information \& Management, Vol. 45 No. 6, pp. 359-364.

Lovelock Chistopher, Jochen Wirtz dan Jacky Mussry (2010), "Pemasaran Jasa” Penerbit Erlangga.

Maxham, J.G. and Netemeyer, R.G. (2002), "Modeling customer perceptions of complaint handling over time: the effects of perceived justice on satisfaction and intent",Journal of Retailing, Vol. 78 No. 4, pp. 239-252.

Mitra, A. (2016), "Effect of information content and form on customers' attitude andtransaction intention in mobile banking: moderating role of perceived 
privacy concern",International Journal of Bank Marketing, Vol. 34 No. 7, pp. 1092-1113.

Sampaio Cláudio. H, Ladeira W.J, Santini Fernando De Oliveira (2017),“Apps for mobile banking and customer satisfaction: a cross-cultural study",International Journal of Bank Marketing Vol. 35 Issue: 7, pp.11311151.

Sumarwan Ujang (2011), "Perilaku Konsumen: Teori dan Penerapannya dalam Pemasaran”, Ghalia Indonesia, Bogor.

Tiwari Rajnish and Stephan Buse (2007), "Mobile Services in Banking Sector: The Role of Innovative Business Solutions in Generating Competitive Advantage", in: Proceedings of the 8th International Research Conference on Quality, Innovation and Knowledge Management, New Delhi.

Zahra, Rahmani, Tahvil, Atusa, Honarmand, Hamideh, Yousefi, Houda (2012), "Mobile Banking and Its Benefits", Arabian Journal of Business and Management Review, Vol.2 No.5

$\underline{\text { www.kalsel.antaranews.com }}$ 